Check for updates

Tenterden, Kent

Cite this as: BMJ 2021;373:n1635 http://dx.doi.org/10.1136/bmj.n1635 Published: 24 June 2021

NEWS ANALYSIS

\title{
Covid-19: Should we be worried about reports of myocarditis and pericarditis after mRNA vaccines?
}

\author{
Jacqui Wise looks at the data released by UK and US regulatory agencies this week
}

Jacqui Wise

\section{What is the latest?}

On 23 June the US Centers for Disease Control and Prevention's safety committee said there was a "likely association" between the Pfizer-BioNTech and Moderna covid-19 vaccines and myocarditis and pericarditis in some young adults. The CDC's Advisory Committee on Immunization Practices said there was a higher than expected number of reports of heart inflammation in people aged 16-24 who had received the mRNA vaccines but that the benefits of vaccination still clearly outweighed the risks. ${ }^{1}$

The Vaccine Adverse Event Reporting System (VAERS) had received 1226 preliminary reports of myocarditis and pericarditis after about 300 million doses of the Pfizer and Moderna vaccines up to 11 June. The US Food and Drug Administration said it would add a warning about the risk to information sheets for the mRNA covid vaccines. A joint statement signed by the US Department of Health and Human Services, the CDC, and medical organisations such as the American College of Physicians and American Medical Association emphasised that the side effect was "extremely rare" and that most cases were mild. ${ }^{2}$

\section{Who is affected?}

In the US the confirmed cases have mostly been seen in male adolescents and young adults and occur more often after the second dose than the first. CDC data showed that after 3625574 second doses

administered to men aged 18-24 there were 233 reports of myocarditis or pericarditis, when two to 25 would have been expected. ${ }^{3}$ After 5237262 doses administered to women in this age group 27 cases were seen, against an expected two to 18. Vinay Prasad, a haematologist-oncologist and associate professor in the department of epidemiology and biostatistics at the University of California San Francisco, told The BMJ "There is a clear and large safety signal in young men and a clear but small signal in young women as well."

\section{When did the safety signal first emerge?}

The first reports of a small number of cases of heart inflammation after the Pfizer vaccine came from Israel at the end of April. ${ }^{4}$ On 1 June Israel's health ministry said there was a "probable link" between the vaccine and myocarditis cases. ${ }^{5} \mathrm{~A}$ total of 275 cases of myocarditis were reported in Israel between

December 2020 and May 2021 among more than five million vaccinated people. Most of the cases were in men aged 16-19, usually after the second dose. After the reports the European Medicines Agency started a review, which is expected to report in July.

\section{What is the situation in the UK?}

Up to 16 June the Medicines and Healthcare Products Regulatory Agency had received 53 reports of myocarditis and 33 reports of pericarditis (including one death) after use of the Pfizer-BioNTech vaccine. The latest weekly yellow card reporting figures show that there have been 42 reports of myocarditis (and one death) and 77 reports of pericarditis after the Oxford-AstraZeneca vaccine and three reports of myocarditis and one report of pericarditis after the Moderna vaccine. ${ }^{6}$

An MHRA spokesperson said, “The number of reports of myocarditis and pericarditis reported with the vaccines in the UK remains similar or below the expected background rate in different age groups within the general population and does not currently indicate an increased risk following vaccination against covid-19. We will continue to closely monitor these events reported in the UK and internationally." The MHRA did not publish a breakdown of the age profile of the reports.

\section{Is myocarditis serious?}

Symptoms of myocarditis and pericarditis can vary but often include shortness of breath, a forceful heartbeat that may be irregular, and chest pain. Heart inflammation is a complication seen with a range of viral infections, including SARS-CoV-2 itself. The European Medicines Agency said that, depending on the source, the incidence of myocarditis and pericarditis ranges from 1 to 10 in 100 ooo people a year.

John Greenwood, president of the British Cardiovascular Society and a consultant cardiologist at Leeds Teaching Hospitals NHS Trust, told The BMJ, "Myocarditis is not an uncommon condition and it can be associated with many different viruses. In our hospital, for example, we may have one or more patients per week suspected of having it.” He added, "For the vast majority of people myocarditis is a benign, self-limiting condition and can be easily treated with NSAIDs. For a very small number of people the heart muscle can become impaired."

\section{Is this association or causation?}

"The fact that it is relatively common, particularly in younger adults, and high numbers of the population have now received covid vaccination, makes it more difficult to determine whether the relationship to 
vaccination is association or causation," said Greenwood. Spotting the "signal" of vaccine induced thrombotic thrombocytopenia (VITT) was easier, because this was a much rarer condition, he explained.

Both the UK yellow card scheme and VAERS in the US rely on voluntary reporting from medical staff and members of the public. An MHRA spokesperson said, "The nature of yellow card reporting means that reported events are not always proven side effects. Some events may have happened anyway, regardless of vaccination. This is particularly the case when millions of people are vaccinated.

Many factors have to be considered when assessing whether the vaccine has caused a reported adverse reaction."

Prasad added, "VAERS is a suboptimal system of surveillance. It relies on providers making a mental connection and putting in effort. For truly extraordinary things such a system is good. It can find a needle in a haystack, but for meaningful excess in common events it is deeply suboptimal."

\section{What does this mean for young people?}

Kamlesh Khunti, professor of primary care diabetes and vascular medicine at the University of Leicester and a member of the government's Scientific and Advisory Group for Emergencies, told The BMJ, "The number of reports are very small compared with the millions who have been given the vaccine, and patients are recovering quickly after being treated with NSAIDs (some may require steroids). Overall the risk-benefit ratio is in favour of giving the vaccine." He added, "Infection rates are still high in younger people, and we are now seeing increasing numbers of young people coming into hospital with complications of covid-19. And young people are also at risk of developing long covid."

The Joint Committee on Vaccination and Immunisation has not yet made a formal decision on vaccinating people aged under 18 in the UK once the adult vaccine campaign is complete. But in the US the CDC said it continued to recommend vaccination for everyone over 12 years of age. The Advisory Committee on Immunization Practices presented data showing that even among young men there were relatively few myocarditis cases given the total number of covid-19 cases prevented. Among adolescent boys ages 12 to 17 the researchers estimated that, for every one million second dose vaccinations, 5700 covid-19 cases, 215 hospital admissions, 71 intensive care unit admissions, and two deaths would be prevented. Against this there might be an estimated 56 to 69 cases of myocarditis.

Prasad believes that the US decision is wrong and that it is better to play it safe. "Vaccination always serves two purposes," he said, "firstly to benefit the person who gets it and secondly to benefit others. We are willing to do things for the second purpose but not if they are a net harm to individuals." He thinks that the US should suspend all vaccination in children under 18 and give only one dose of vaccine to men under 25 .

1 Centers for Disease Control and Prevention. Selected adverse events reported after covid-19 vaccination. Jun 2021. https://www.cdc.gov/coronavirus/2019-ncov/vaccines/safety/adverseevents.html.

2 US Department of Health and Human Services. Statement following CDC ACIP Meeting from nation's leading doctors, nurses and public health leaders on benefits of vaccination. Jun 2021. https://www.hhs.gov/about/news/2021/06/23/statement-following-cdc-acip-meeting-nationsleading-doctors-nurses-public-health-leaders-benefits-vaccination.html.

3 Shimabukuro T. Covid-19 vaccine safety updates Advisory Committee on Immunization Practices (ACIP). June 2021. ttps://www.cdc.gov/vaccines/acip/meetings/downloads/slides-2021-06/03COVID-Shimabukuro-508.pdf.

4 Ministry of Health. Surveillance of myocarditis (inflammation of the heart muscle) cases between December 2020 and May 2021 (including). June 2021. https://www.gov.il/en/departments/news/01062021-03.
5 Reurers. Israel examining heart inflammation cases in people who received Pfizer COVID shot. Apr 2021. https://www.reuters.com/world/middle-east/israel-examining-heart-inflammationcases-people-who-received-pfizer-covid-shot-2021-04-25.

$6 \quad$ MHRA. Coronavirus vaccine: weekly summary of Yellow Card reporting. Jun 2021. https://www.gov.uk/government/publications/coronavirus-covid-19-vaccine-adverse-reactions/coronavirus-vaccine-summary-of-yellow-card-reporting.

This article is made freely available for use in accordance with BMJ's website terms and conditions for the duration of the covid-19 pandemic or until otherwise determined by BMJ. You may use, download and print the article for any lawful, non-commercial purpose (including text and data mining) provided that all copyright notices and trade marks are retained. 